\title{
INISIASI MENYUSU DINI MENJAGA KESTABILAN SUHU PADA BAYI BARU LAHIR
}

\section{EARLY BREASTFEEDING INITIATION KEEP TEMPERATURE STABILITY IN THE NEWBORN}

\author{
Nuli Nuryanti Zulala ${ }^{1 *}$, Mei Neni Sitaresmi², Sulistyaningsih ${ }^{3}$
}

\begin{abstract}
${ }^{*}$ Program Studi Kebidanan Diploma III, Fakultas IImu Kesehatan, Universitas 'Aisyiyah Yogyakarta JI. Ring Road Barat No 63 Mlangi Nogotirto Gamping Sleman Yogyakarta 55292,

Email : nuli.zulala@unisayogya.ac.id, Indonesia.

2 Departemen IImu Kedokteran Anak, Fakultas Kedokteran, Kesehatan Masyarakat dan Keperawatan Universitas Gadjah Mada Jl. Farmako Sekip Utara Yogyakarta 55281, Indonesia.

${ }^{3}$ Program Studi Kebidanan Diploma III, Fakultas IImu Kesehatan, Universitas 'Aisyiyah Yogyakarta JI. Ring Road Barat No 63 Mlangi Nogotirto Gamping Sleman Yogyakarta 55292, Indonesia.
\end{abstract}

\begin{abstract}
Background: Hypothermia contributes $6.3 \%$ to neonatal mortality. Interventions to keep newborns warm can reduce neonatal mortality by $18-42 \%$. Early Breastfeeding Initiation (EBI) is a simple intervention that reduces the risk of neonatal death.

Objective: The aim of this study to determine the difference of axillary temperature of newborn between improper EBI group and proper EBI group for 24 hours.

Methods: This prospective cohort study was conducted at Aisyiyah Muntilan Hospital. Sixty-two healthy newborns from healthy mothers born in November 2016 who meet the inclusion and exclusion criteria. Subjects were grouped in improper EBI groups $(n=32)$ and proper EBI groups $(n=32)$. Axila temperature measurements were performed at $1^{\text {st }}$ minute, $30^{\text {th }}$ minute, $60^{\text {th }}$ minute, $6^{\text {th }}$ hour, $12^{\text {th }}$ hour, $24^{\text {th }}$ hour.

Results: The result of the hypotermic occurrence is more happened on improper $\mathrm{EBI}$ than proper $\mathrm{EBI}$. $\mathrm{EBI}$ is able to prevent hypothermia during the first 24 hours of newborn life

Conclussions: Infants with proper EBI have a lower risk of hypothermia.
\end{abstract}

Keyword: Early Breastfeeding Initiation, Hypothermia, Newborn

\section{PENDAHULUAN}

Hipotermi merupakan penyebab 6,3\% kematian neonatal. ${ }^{1}$ Tanpa penanganan yang tepat, bayi baru lahir akan kehilangan suhu tubuhnya $0,1^{\circ} \mathrm{C}-0,3^{\circ} \mathrm{C}$ setiap menitnya. ${ }^{2}$ WHO Concultative Group on Thermal Control menyatakan bayi baru lahir tanpa penanganan yang tepat akan mengalami penurunan suhu tubuh antara $2-4^{\circ} \mathrm{C}$ dalam 10-30 menit setelah kelahiran. ${ }^{3,4}$ Mekanisme pengaturan suhu tubuh bayi baru lahir belum berfungsi sempurna sehingga mudah terjadi hipotermia. Penelitian Farhadi et al. (2014) dan Lunze et al. (2013) menyebutkan kejadian hipotermi pada bayi baru lahir cukup tinggi, secara global berkisar 8,5\%-52\%, diperkirakan 17 juta bayi baru lahir mengalami hipotermia di negara terbelakang. ${ }^{5,6}$ Prevalensi hipotermi di Indonesia belum diketahui, namun penelitian (Pratiwi et al., 2009) di Sanglah Bali menunjukkan $47 \%$ kejadian hipotermi pada bayi yang tidak dilakukan IMD dan 27\% pada bayi yang dilakukan IMD. ${ }^{7}$

Hipotermia terjadi pada bayi baru lahir yang tubuhnya tidak segera dikeringkan 
dan diselimuti, intervensi untuk menjaga bayi baru lahir tetap hangat dapat menurunkan kematian neonatal sebanyak $18-42 \% .^{8}$ Suhu yang dingin dapat menyebabkan tubuhnya secara alamiah membakar cadangan lemak untuk mendapatkan suhu tubuh yang sesuai, cadangan yang terbatas ini tidak akan bertahan lama, sehingga bayi perlu dihangatkan dengan cara dipeluk oleh ibunya, bersentuhan antara kulit bayi dengan kulit ibu tanpa pelapis apapun. ${ }^{6}$ IMD merupakan proses kontak kulit ke kulit antara ibu dan bayinya segera setelah lahir minimal satu jam. ${ }^{9}$ IMD merupakan intervensi sederhana yang mampu meningkatkan neonatal outcome secara signifikan yaitu mengurangi risiko kematian neonatal. ${ }^{10}$ Penelitian di Ghana menyebutkan IMD dapat menyelamatkan $22 \%$ dari bayi yang meninggal sebelum usia satu bulan, IMD disebut sebagai tindakan penyelamatan kehidupan. ${ }^{11}$ Kontak kulit ke kulit segera setelah lahir memberikan manfaat bagi ibu dan bayi, meningkatkan ikatan kasih sayang, meningkatkan durasi menyusui, menstabilkan suhu tubuh, menstabilkan pernafasan, nadi serta glukosa darah bayi. ${ }^{12}$

\section{BAHAN DAN CARA PENELITIAN}

Penelitian observasional dengan rancangan kohort prospektif ini mengamati bayi baru lahir yang dilakukan IMD tepat dan yang tidak dilakukan IMD dengan tepat, kemudian melakukan pengukuran suhu pada dua kelompok tersebut pada menit ke-1, menit ke-30 dan menit ke-60 serta pada jam ke-6, jam ke-12 dan jam ke-24.

Populasi penelitian ini adalah seluruh bayi yang dilahirkan pada bulan November 2016 di Rumah sakit 'Aisyiyah Muntilan sejumlah 74 responden.

Kriteria inklusi penelitian yaitu seluruh bayi baru lahir sehat (APGAR Score 7-10) yang lahir di Rumah sakit 'Aisyiyah Muntilan. Kriteria eksklusi penelitian yaitu bayi baru lahir dengan asfiksia dan tidak berhasil dilakukan resusitasi awal, berat badan lahir bayi <2000 gr, bayi dengan kelainan kongenital (misal anenchepal, hidrocepalus) ,ibu mengalami perdarahan,ibu mengalami kejang.

Teknik pengambilan sampel dalam penelitian ini menggunakan non probability sampling dengan metode consecutive sampling, subyek penelitian dipilih berdasarkan kriteria sampai dengan kurun waktu tertentu sehingga jumlah sampel yang diperlukan terpenuhi.

Berdasarkan perhitungan rumus besar sampel bahwa jumlah sampel yang yang diperoleh adalah 28 untuk tiap kelompok dan dilakukan penambahan responden sebanyak $10 \%$ untuk mengantisipasi kemungkinan terjadinya subyek penelitian yang terpilih drop out maka keseluruhan jumlah sampel menjadi 62 responden.

Instrumen penelitian yang digunakan adalah lembar observasi pelaksanaan IMD yang mengacu pada buku Panduan 
Operasional Pelayanan Persalinan dan Nifas

Normal Bagi tenaga Kesehatan, Kemenkes
2015, lembar observasi suhu dan alat pengukur suhu axila digital.

\section{HASIL DAN PEMBAHASAN}

Tabel 1. Karakteristik Responden

\begin{tabular}{|c|c|c|c|c|}
\hline Karakteristik & $\begin{array}{c}\text { IMD tidak tepat } \\
\mathrm{n}(\%)\end{array}$ & $\begin{array}{c}\text { IMD tepat } \\
\mathrm{n}(\%)\end{array}$ & $\begin{array}{c}\text { Jumlah } \\
(\mathrm{n}=62)\end{array}$ & $\begin{array}{c}\text { Proporsi } \\
(\%)\end{array}$ \\
\hline \multicolumn{5}{|l|}{ Karakteristik bayi } \\
\hline \multicolumn{5}{|l|}{ Berat lahir bayi } \\
\hline 2000 - 2499 gram & $2(6,5)$ & $3(9,7)$ & 5 & 8,1 \\
\hline \multicolumn{2}{|l|}{ Jenis kelamin bayi } & $28(90,3)$ & 57 & 91,9 \\
\hline Laki-laki & $20(64,5)$ & $13(41,9)$ & 33 & 53,2 \\
\hline Perempuan & $11(35,5)$ & $18(58,1)$ & 29 & 46,8 \\
\hline \multicolumn{5}{|l|}{ Karakteristik ibu } \\
\hline \multicolumn{5}{|l|}{ Umur kehamilan } \\
\hline$<37$ minggu & $1(3,2)$ & $1(3,2)$ & 2 & 3,2 \\
\hline \multicolumn{4}{|l|}{ Cara persalinan } & 96.8 \\
\hline Sectio caesaria & $20(64,5)$ & $1(3,2)$ & 21 & 33,9 \\
\hline Pervaginam & $11(35,5)$ & $30(96,8)$ & 41 & 66,1 \\
\hline \multicolumn{5}{|l|}{ Usia ibu } \\
\hline $20-35$ tahun & $24(77,4)$ & $25(80,6)$ & 49 & 79 \\
\hline$>35$ tahun & $7(22,6)$ & $6(19,4)$ & 13 & 21 \\
\hline \multicolumn{5}{|l|}{ Status obstetric } \\
\hline Primipara & $10(32,3)$ & $10(32,3)$ & 20 & 32,3 \\
\hline Multipara & $21(67,7)$ & $21(67,7)$ & 42 & 67,7 \\
\hline \multicolumn{5}{|l|}{ Pendidikan ibu } \\
\hline SD & $2(6,4)$ & $0(0)$ & 2 & 3,2 \\
\hline SLTP & $2(6,4)$ & $6(19,4)$ & 8 & 12,9 \\
\hline SLTA & $18(58,2)$ & $15(48,4)$ & 33 & 53,2 \\
\hline D3 & $4(12,9)$ & $4(12,9)$ & 8 & 12,9 \\
\hline S1 & $5(16,1)$ & $5(16,1)$ & 10 & 16,1 \\
\hline S2 & $0(0)$ & $1(3,2)$ & 1 & 1,6 \\
\hline \multicolumn{5}{|l|}{ Pekerjaan } \\
\hline Guru & $2(6,4)$ & $2(6,4)$ & 4 & 6,5 \\
\hline IRT & $17(54,8)$ & $15(48,4)$ & 32 & 51,6 \\
\hline Petani & $1(3,2)$ & $1(3,2)$ & 2 & 3,2 \\
\hline PNS & $1(3,2)$ & $0(0)$ & 1 & 1,6 \\
\hline Swasta & $7(22,6)$ & $12(38,8)$ & 19 & 30,6 \\
\hline Wiraswasta & $3(9,8)$ & $1(3,2)$ & 4 & 6,5 \\
\hline
\end{tabular}

Karekteristik responden meliputi karakteristik bayi dan ibu. Karakteristik responden kelompok IMD tidak tepat pada bayi mayoritas memiliki berat badan $\geq 2500$ gram dan berjenis kelamin laki-laki. Pada karakteristik ibu mayoritas umur kehamilan $\geq 37$ minggu, cara persalinan dengan sectio caesaria, berusia 20-35 tahun dengan status obstetrik multipara, pendidikan SLTA serta pekerjaan IRT.

Karakteristik responden kelompok IMD tepat pada bayi mayoritas memiliki berat lahir $\geq 2500$ gram dan berjenis kelamin perempuan. Pada karakteristik ibu mayoritas 
umur kehamilan $\geq 37$ minggu, cara persalinan

pervaginam, berusia 20-35 tahun dengan status obstetrik multipara, pendidikan SLTA serta pekerjaan IRT.

Tabel 2. Pelaksanaan IMD

\begin{tabular}{|c|c|c|c|}
\hline No & Kegiatan & $\mathbf{N}$ & $\%$ \\
\hline 1 & Membersihkan tubuh bayi tanpa membersihkan verniks & & \\
\hline a & Meletakan kain kering dan hangat diatas perut ibu & 41 & 66,1 \\
\hline $\mathrm{b}$ & $\begin{array}{l}\text { Melakukan penilaian selintas dan meletakkan bayi diatas } \\
\text { perut ibu }\end{array}$ & 41 & 66,1 \\
\hline c & $\begin{array}{l}\text { Mengeringkan bayi mulai dari muka, kepala dan bagian } \\
\text { tubuh lainnya kecuali bagian tangan tanpa membersihkan } \\
\text { verniks }\end{array}$ & 62 & 100 \\
\hline$d$ & $\begin{array}{l}\text { Segera mengganti handuk basah dengan handuk atau kain } \\
\text { yang kering }\end{array}$ & 62 & 100 \\
\hline 2 & Melakukan kontak kulit ibu ke kulit bayi & & \\
\hline a & $\begin{array}{l}\text { Meletakkan bayi di dada atau perut ibu dalam posisi } \\
\text { telungkup agar ada kontak kulit ibu ke kulit bayi, }\end{array}$ & 55 & 88,7 \\
\hline $\mathrm{b}$ & Melakukan kontak kulit ke kulit selama minimal 1 jam & 31 & 50,0 \\
\hline 3 & Membiarkan bayi mencari puting ibunya tanpa intervensi & 55 & 88,7 \\
\hline
\end{tabular}

menyatakan bayi baru lahir dengan sectio

Pelaksanaan IMD belum berjalan dengan optimal. Langkah I membersihkan tubuh bayi tanpa membersihkan vernik hanya pada proses mengeringkan bayi dan mengganti handuk basah dengan handuk kering yang dilakukan sempurna, meletakan kain kering dan hangat diatas perut ibu serta melakukan penilaian selintas dan meletakan bayi diatas perut ibu terhalang pada persalinan dengan sectio caesaria. Dalam proses langkah II melakukan kontak kulit ibu ke kulit bayi selama minimal 1 jam masih sangat rendah, dimana proses ini merupakan tolak ukur dalam keberhasilan IMD.

Hasil penelitian ini sejalan dengan penelitian Horn et al., (2014) yang caesaria yang tidak dilakukan kontak kulit ke

kulit dengan ibunya mengalami penurunan suhu $0,6^{\circ} \mathrm{C} .{ }^{11}$ Shwetal et al,. (2012) menyatakan sectio caesaria menjadi penghalang utama dalam pelaksanaan IMD, ibu mengalami kelelahan, kurang percaya diri untuk melakukan kontak kulit ke kulit dengan bayi, serta efek dari anastesi yang menjadikan tertunda atau tidak terlaksananya IMD sehingga mengakibatkan berkurangnya sekresi air susu ibu. ${ }^{13}$

Pemerintah telah memberikan pedoman melalui Peraturan Pemerintah No 33 Tahun 2012 tentang pemberian Air Susu lbu Eksklusif, pada Pasal 9 disebutkan tenaga kesehatan dan penyelenggara fasilitas 
pelayanan kesehatan wajib melakukan Inisiasi Menyusu Dini (IMD) terhadap bayi yang baru lahir kepada ibunya paling singkat selama 1 (satu) jam. Pada Pasal 10 disebutkan tenaga kesehatan dan fasilitas pelayanan kesehatan wajib menempatkan ibu dan bayi dalam 1 ruangan atau rawat gabung kecuali atas indikasi medis. Pasal 13 menyebutkan tenaga kesehatan dan penyelenggara fasilitas kesehatan wajib memberikan informasi dan edukasi mengenai ASI Eksklusif kepada ibu adan atau anggota keluarga sejak pemeriksaan kehamilan hingga periode pemberian ASI Eksklusif selesai.
Temuan USAID-KINERJA tahun 2014, kegagalan IMD serta ASI Eksklusif karena kurangnya pengetahuan mengenai manfaat dari IMD dan ASI Eksklusif sedangkan dari sisi pemberi layanan hambatan yang muncul adalah rendahnya anggaran yang mendukung program, bervariasinya komitmen, pemahaman dan kesadaran tenaga kesehatan, terbatasnya waktu dan sarana petugas dalam memberikan konseling, gencarnya promosi susu formula, fasilitas yang belum memadai serta kurangnya pengawasan terhadap petugas. $^{14}$

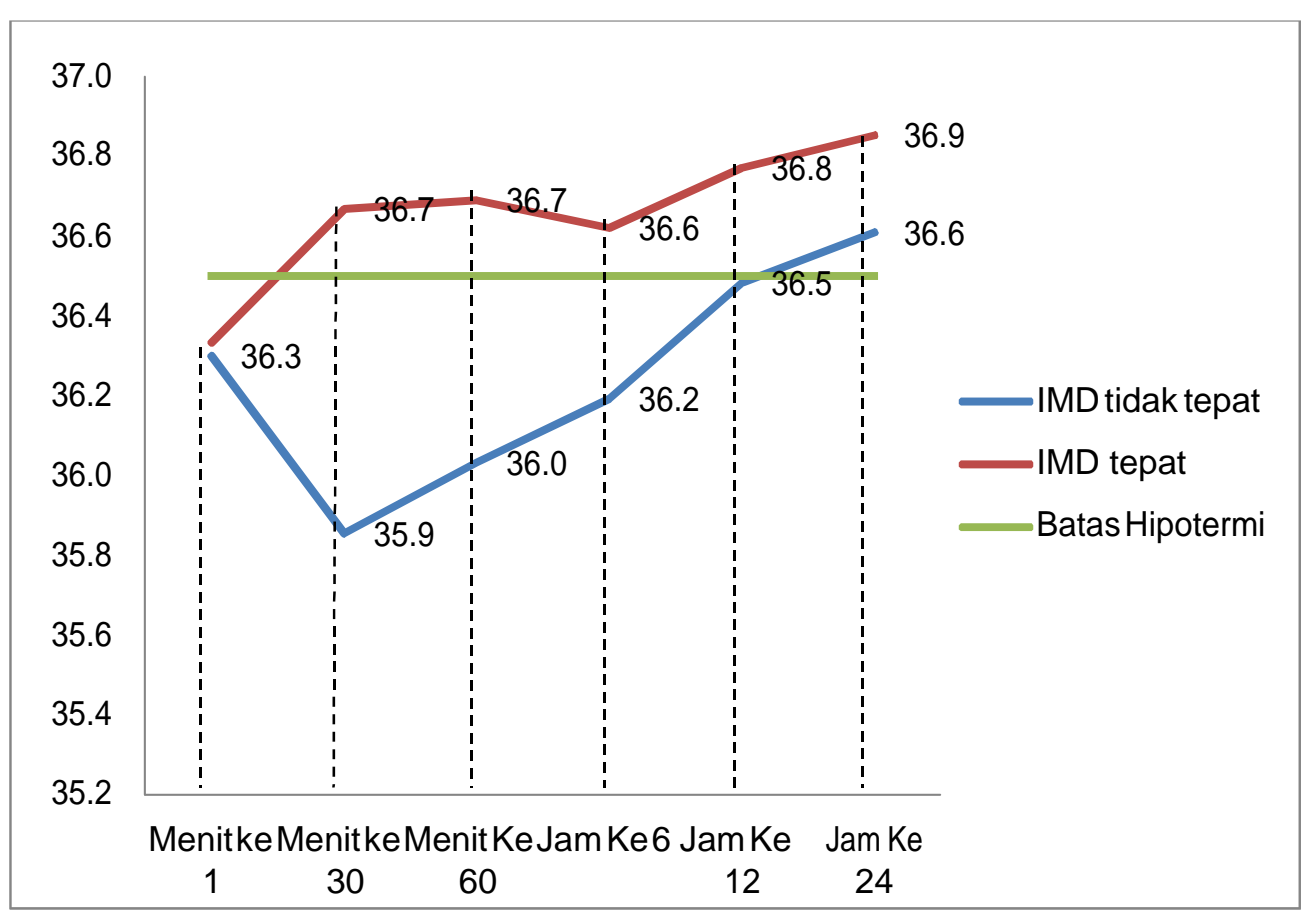

\section{Gambar 1. Grafik Hasil Uji Beda Rerata Suhu Kelompok IMD TidakTepat dan IMD Tepat}

Berdasarkan gambar 1 pada menit ke-1 rerata suhu antara kelompok IMD tidak tepat dan IMD tepat sama yaitu $36,3^{\circ} \mathrm{C}$ selanjutnya terdapat perbedaan suhu axila bayi pada pengukuran berikutnya, perubahan rerata suhu pada kelompok IMD tidak tepat terjadi penurunan suhu pada menit ke-30 kemudian meningkat pada menit selanjutnya 
sedangkan pada kelompok IMD tepat mengalami peningkatan dari menit ke-1 ke menit ke-30 dan menit ke-60 kemudian menurun $0,1^{\circ} \mathrm{C}$ pada jam ke- 6 kemudian menjadi stabil pada jam selanjutnya, namun rerata suhu pada kelompok IMD tidak tepat lebih rendah dari kelompok IMD tepat.

Hasil penelitian ini mendukung beberapa penelitian sebelumnya Hutagaol et al., (2014) yang menyatakan bahwa rerata suhu aksila kelompok IMD lebih tinggi dari rerata suhu aksila pada kelompok yang tidak dilakukan IMD yaitu sebesar 37,1 $\pm 0,20 \mathrm{C}$ dan 36,8 $\pm 0,40$ C. $^{15}$ Penelitian Gabriel et al., (2010) juga menunjukkan peningkatan suhu pada bayi yang dilakukan IMD $\left(1,6 \pm 1,5^{\circ} \mathrm{C}\right.$ dengan rerata $37,1^{\circ} \mathrm{C}$ ) dan penurunan suhu pada bayi yang tidak dilakukan IMD $\left(0,07 \pm 0,58^{\circ} \mathrm{C}\right.$ dengan rerata $\left.36,7^{\circ} \mathrm{C}\right) .{ }^{16}$ Penelitian Srivastava Smita et al. (2014) menunjukkan pada kelompok IMD memberikan kontribusi yang lebih baik pada kemampuan menjaga kestabilan suhu bayi. ${ }^{17}$ Kosim et al., (2014) dan Behrmen et al., (2000) menyatakan bahwa bayi baru lahir tanpa penanganan yang tepat akan kehilangan panas empat kali lebih besar dari pada orang dewasa, sehingga mengakibatkan terjadinya penurunan suhu, tubuh antara $2-4^{\circ} \mathrm{C}$ dalam 10-30 menit setelah kelahiran. ${ }^{3,4}$

IMD mampu menjaga kestabilan suhu bayi baru lahir sehingga dapat mencegah kejadian hipotermia yang menjadi penyebab kematian pada bayi baru lahir, serta mampu memfasilitasi kemampuan bayi dalam menggunakan seluruh indra, pengelihatan, pendengaran, bau, rasa dan gerak dan mengoptimalkan kemampuan pengaturan tubuh bayi hingga tahun pertama kehidupannya. ${ }^{18,19}$

IMD menyebabkan stimulasi vagal lewat rangsangan sentuhan dan bau serta menginduksi pelepasan hormon oxytosin pada ibu sehingga menyebabkan suhu payudara ibu meningkat yang dapat menjaga suhu bayi saat dilakukan IMD. Kulit ibu merupakan termoregulator yang tepat bagi bayi, suhu kulit dada ibu akan menyesuaikan dengan suhu tubuh bayi, jika bayi kedinginan, suhu kulit ibu naik dua derajat secara otomatis untuk menghangatkan bayi sehingga menurunkan risiko hipotermi, ketika suhu bayi meningkat maka suhu kulit ibu otomatis turun satu derajat untuk menstabilkan suhu bayi. ${ }^{17}$

Penelitian Fransoon et al., (2005) menyebutkan peningkatan suhu kulit kaki tertinggi pada jam pertama bayi baru lahir selama bayi diletakkan dekat dengan ibu. Rerata suhu kulit perut kelompok IMD juga lebih tinggi dibandingkan rerata suhu kulit perut kelompok yang tidan IMD. Suhu kulit kaki terendah terjadi pada saat bayi berada dalam kain atau bedong tanpa dilakukan IMD.20

IMD merupakan intervensi sederhana yang mampu meningkatkan neonatal outcome secara signifikan yaitu mengurangi risiko kematian neonatal, membantu dalam 
keberlangsungan pemberian ASI eksklusif dan periode lama menyusui. Penelitian di Ghana menyebutkan IMD dapat menyelamatkan $22 \%$ dari bayi yang meninggal sebelum usia satu bulan, menunda pelaksanaan IMD dalam pencegahan hipotermi pada bayi baru lahir meningkatkan 6 kali risiko kematian neonatal. ${ }^{10,21,22}$ Tidak segera mengeringkan bayi setelah mandi dapat menyebabkan penurunan suhu tubuh bayi, menunda memandikan bayi minimal sampai 6 jam setelah lahir akan menjadikan bayi lebih sehat dan menjaga suhu tetap stabil. ${ }^{23,24}$

Petugas kesehatan memiliki peran yang sangat penting dalam pelaksanaan IMD yang dipengaruhi oleh sikap, pengetahuan dan motivasi serta didukung oleh suami, keluarga, dan masyarakat. Informasi dan dukungan sangat diperlukan bagi ibu dan keluarga dimulai sejak kehamilan sedangkan dukungan tenaga kesehatan melalui pemberian KIE, sosialisasi serta media berupa leaflet, banner merupakan faktor yang paling memperkuat keberhasilan pelaksanaan IMD. ${ }^{25,26,27,28,29,30}$

Dukungan bidan dan tenaga kesehatan sangat penting dalam implementasi IMD, penelitian Syam dan Amiruddin (2015) menunjukkan bahwa ibu yang memperoleh dukungan dari bidan dan tenaga kesehatan memiliki tingkat keberhasilan melakukan IMD 17.5 kali lebih besar dari ibu yang tidak mendapatkan dukungan dari bidan dan tenaga kesehatan. ${ }^{31}$ Tenaga kesehatan memiliki tanggung jawab dan peran yang penting dalam melaksanakan IMD sebagai intervensi mencegah hipotermi sehingga dapat meningkatkan neonatal outcome. $^{32}$ Bidan sesuai kewenangannya yang diatur dalam Permenkes No 369 tentang standar profesi bidan pada kompetensi ke-4 mengenai asuhan persalinan dan kelahiran bidan harus memiliki pengetahuan dasar transisi bayi baru lahir terhadap kehidupan diluar rahim, pemenuhan kebutuhan fisik BBL meliputi pernafasan, kehangatan, termasuk memfasilitasi IMD. Ikatan Bidan Indonesia (IBI) dalam prosedur Asuhan Persalinan Normal (APN) atau panduan dalam pertolongan persalinan fisiologis bagi bidan menetapkan mekanisme pencegahan hipotermi dan IMD sebagai asuhan sayang bayi. ${ }^{33}$

\section{KESIMPULAN}

Inisiasi Menyusu Dini (IMD) tepat mampu mencegah hipotermi dan menjaga kestabilan suhu bayi baru lahir hingga 24 jam kehidupan pertamanya.

\section{TERIMA KASIH}

1. dr. Moh Was'an, Sp.S (K), QIA, Direktur Rumah Sakit 'Aisyiyah Muntilan. Kesehatan Neonatal Esensial [Internet].

\section{KEPUSTAKAAN}

1. Kemenkes. Buku Saku Pelayanan

Inisiasi Menyusu Dini Menjaga Kestabilan Suhu Pada Bayi Baru Lahir 
2010. xviii. Available from: http://www.gizikia.depkes.go.id/wpcontent/uploads/downloads/2011/09/Buku -Saku-Pelayanan-Kesehatan-NeonatalEsensial.pdf

2. Boutilier RG. Mechanisms of cell survival in hypoxia and hypothermia. J Exp Biol. 2001;204(Pt 18):3171-81.

3. Kosim MS, Yunanto A, Dewi R, Sarosa GI, Usman A. Buku Ajar Neonatologi. Jakarta: Badan Penerbitan IDAI; 2014.

4. Behrmen R, Kliegman R, Arvin A. Ilmu Kesehatan Anak Nelson. Jakarta: EGC; 2000.

5. Farhadi $R$, Rezai mohammad $S$, Nakhshab M. Incidence of neonatal hypothermia at birth in hospitals of Islamic Republic of Iran: a review. J Pediatr Rev. 2014;2(2):21-30.

6. Lunze K, Bloom DE, Jamison DT, Hamer $\mathrm{DH}$. The global burden of neonatal hypothermia: systematic review of a major challenge for newborn survival. BMC Med [Internet]. 2013;11(24). Available from: http://www.biomedcentral.com/17417015/11/24

7. Pratiwi E, Soetjiningsih, Kardana IM. Effect Of Kangaroo Method On The Risk Of Hypothermia And Duration Of Birth Weight Regain In Low Birth Weight Infant: A Randomized Controlled Trial. Paediatr Indones. 2009;49(5):253-8.

8. McCall E, Alderdice $F$, Halliday $H$, Jenkins $J$, Vohra $S$. Interventions to prevent hypothermia at birth In preterm and / or low birthweight infants ( review ). Cochrane. 2010;(3).

9. WHO. Postnatal Care Of The Mother And Newborn [Internet]. World Health Organization. 2013. 1-72 p. Available from: http://apps.who.int/iris/bitstream/10665/97 603/1/9789241506649_eng.pdf

10. Dyson L, Mccormick F, Renfrew M. Interventions for promoting the initiation of breastfeeding ( review ). Cochrane Database Syst Rev. 2008;(2).

11. Horn E-P, Bein B, Steinfath $M$, Ramaker $\mathrm{K}$, Buchloh B, Hocker J. The incidence and prevention of hypothermia in newborn bonding after cesarean delivery: a randomized controlled trial.
Surv Anesthesiol. 2014;59(1):26-7.

12. Moore ER, Anderson GC, Bergman N, Dowswell T. Early Skin-to-Skin Contact For Mothers And Their Healthy Newborn Infants. The Cochrane. 2014;

13. Shwetal B, Pooja P, Neha K, Amit D, Rahul P. Knowledge, Attitude And Practice Of Postnatal Mothers For Early Initiation Of Breast Feeding In The Obstetric Wards Of A Tertiary Care Hospital Of Vadodara City. Natl J Community Med. 2012;3(2):305-9.

14. USAID, KINERJA. Tata Kelola Inisiasi Menyusu Dini Dan Asi Eksklusif. 2014.

15. Hutagaol HS, Darwin E, Yantri E. Pengaruh Inisiasi Menyusu Dini ( IMD ) terhadap Suhu dan Kehilangan Panas pada Bayi Baru Lahir. J Kesehat Andalas [Internet]. 2014;3(3):332-8. Available from: http://jurnal.fk.unand.ac.id

16. Gabriel MAM, Martín IL, Escobar AL, Villalba EF, Blanco IR, Pol PT. Randomized controlled trial of early skinto-skin contact: Effects on the mother and the newborn. Acta Paediatr Int J Paediatr. 2010;99(11):1630-4.

17. Srivastava S, Gupta A, Bhatnagar A, Dutta S. Effect of Very Early Skin to Skin Contact on Success at Breastfeeding and Preventing Early Hypothermia in Neonates. Indian J Public Health. 2014;58(1).

18. Widström A, Lilja G, Dahllöf A, Lintula $M$, Nissen E. Newborn behaviour to locate the breast when skin-to-skin: a possible method for enabling early selfregulation. Acta Pediatr. 2011;79-85.

19. Thukral A, Sankar MJ, Agarwal R, Gupta N, Daeorari A, Paul V. Early Skin- to-Skin Contact and Breast-Feeding Behavior in Term Neonates: A Randomized Controlled Trial. Neonatology. 2012;102:114-9.

20. Fransoon A-L, Karlsson H, Nilsson K. Temperature Variation In Newborn Babies: Importance Of Physical Contact With The Mother. Arch Dis Child Fetal Neonatal. 2005;500-4.

21. Edmond KM, Zandoh C, Quigley MA, Amenga-etego S, Owusu-agyei $S$. Delayed breastfeeding initiation increases risk of neonatal mortality. Pediatrics. 2006;117(3). 
22. Roesli U. Inisiasi Menyusu Dini Plus ASI Eksklusif. Jakarta: Pustaka Bunda; 2008.

23. WHO. Thermal Protection Of Newborn: A Practical Guide [Internet]. 1997. Available from: http://apps.who.int/iris/bitstream/10665/63 986/1/WHO_RHT_MSM_97.2.pdf

24. Kumar V, Shearer JC, Kumar A, Darmstadt GL. Neonatal hypothermia in Low Resource Settings: A Review. J Perinatol [Internet]. Nature Publishing Group; 2009;29(6):401-12. Available from: http://dx.doi.org/10.1038/jp.2008.233

25. Fikawati S, Syafiq A. Kajian Implementasi Kebijakan Air Susu lbu Eksklusif Dan Inisiasi Menyusu Dini di Indonesia. Makara Kesehat. 2010;14(1):17-24.

26. Nahidi F, Tavafian SS, Haidarzade M. Midwifes 'Opinions about Reinforcing Factors in Skin to Skin Contact, Immediately After Delivery: A Descriptive Study. Heal Educ Heal Promot. 2013;1(2).

27. Mujiati, Novianti. Pelaksanaan Sosialisasi Inisiasi Menyusu Dini ( IMD ) di Rumah Sakit St Carolus dan Rumah Sakit Umum Daerah ( RSUD ) Budhi Asih Jakarta. Bul Penelit Kesehat. 2015;43(4):247-56.

28. UNICEF. The Evidence and Rationale for the UNICEF UK Baby Friendly Initiative Standards. 2013; Available from: https://www.unicef.org.uk/wpcontent/uploads/sites/2/2013/09/baby_frie ndly_evidence_rationale.pdf

29. Debes AK, Kohli A, Walker N, Edmond K, Mullany LC. Time to Initiation of Breastfeeding and Neonatal Mortality and Morbidity: a Systematic Review. BMC Public Health [Internet]. 2013;13(Suppl 3). Available from: http://www.biomedcentral.com/14712458/13/S3/S19REVIEW

30. Lutfiyati A, Haryanti F, Lusmilasari L. Faktor-faktor yang Berhubungan dengan Inisiasi Menyusu Dini (IMD) di Kabupaten Bantul. Media IImu Kesehat. 2017;6(2):168-76.

31. Syam A, Amiruddin R. Inhibitor Factors of Early Initiation of Breastfeeding among Mothers in Rural District Bone, South Sulawesi, Indonesia. Asian J Epidemiol. 2015;

32. Mizzi J, Muskat RV. Hypothermia in the early neonatal period: follow-up study. Malta Med J. 2007;19(1).

33. Kemenkes. Panduan Operasional Pelayanan Persalinan dan Nifas Normal Bagi Tenaga Kesehatan. Jakarta; 2015. 